\title{
The preparation of $\mathrm{Ag}_{3} \mathrm{BiBr}_{6}$ films and their preliminary use for solution processed photovoltaics
}

\author{
Jia Tu${ }^{1} \cdot$ Chun Kou ${ }^{1} \cdot$ Meili Liu ${ }^{1} \cdot$ Hao Lu ${ }^{2} \cdot$ Yahui Liu $^{1} \cdot$ Hongwei Tan ${ }^{1} \cdot$ Wenhua Li ${ }^{1} \cdot$ Zhishan Bo $^{1}$
}

(c) Springer Nature Switzerland AG 2019

\begin{abstract}
Bismuth-halide-based perovskites could be promising candidates for construction of lead-free and air-stable perovskites solar cells. Herein we report a simple strategy on the fabrication of the $\mathrm{Ag}_{3} \mathrm{BiBr}_{6}$ thin films. They were prepared by flexible spin-coating procedure and the solvent of $\mathrm{N}$-butylamine is found to be critical to dissolving $\mathrm{AgBr}$ precursor solution under lower room temperatures. Experiment and calculation analysis both reveal it with hexagonal structure. Their physical properties and photovoltaic performance were both characterized. We demonstrate that $\mathrm{Ag}_{3} \mathrm{BiBr}_{6}$ films are capable of storing stably over 30 days in air. These results will inspire more research works on developing and applying $\mathrm{Ag}_{3} \mathrm{BiBr}_{6}$ beyond solar energy applications.
\end{abstract}

Keywords Lead-free perovskite · Solar energy materials · Energy storage and conversion · Thin films

\section{Introduction}

Lead-halide perovskite solar cells (PSCs) have experienced a rapid development since 2009 [1], and their power conversion efficiencies (PCEs) have reached $23.3 \%$ in the past 9 years [2-7]. However, there are some serious issues with them, such as the toxicity of $\mathrm{Pb}$ and poor stability in humidity, which seriously restrict their further development towards commercial use [8-11]. Thus, Pb-free light absorbers have been diversely investigated over several

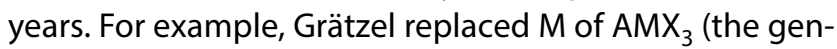
eral formula of lead halide perovskites, $A$ and $M=1+$ and $2+$ cations, respectively; $\mathrm{X}=\mathrm{Cl}^{-}, \mathrm{Br}^{-}, \mathrm{I}^{-}$) with $\mathrm{Sn}^{2+}$ and $\mathrm{Ge}^{2+}$ as they all belong to IVA group [11] and the PCE of $\mathrm{CH}_{3} \mathrm{NH}_{3} \mathrm{Snl}_{3}$ has increased to $6 \%$. Unfortunately, $\mathrm{Sn}^{2+}$ cation can be easily oxidized to $\mathrm{Sn}^{4+}$ and $\mathrm{Ge}^{2+}$ sensitive to air due to the low binding energy of its $4 s^{2}$ electrons, [12-16], causing their poor reproducibility. Hence, it is desirable to explore other elements to develop lead-free perovskites.

$\mathrm{Bi}^{3+}$ and $\mathrm{Sb}^{3+}$ feature close electronegativity and ionic radius comparable to $\mathrm{Pb}^{2+}$. More importantly, bismuth halide perovskites exhibit mononuclear or polynuclear with corner-, edge- and/or face- sharing by connecting the adjacent bismuth halide octahedral $[17,18]$. Bi- and Sb- based light absorbers like $A_{3} B_{2} I_{9}, A B i_{3} I_{10}, A_{3} S_{2} I_{9}$ $\left(\mathrm{A}=\mathrm{MA}^{+}, \mathrm{Cs}^{+}\right)$and others have been studied in the light of advantages of $\mathrm{Bi}$ and $\mathrm{Sb}$ [19-22]. These combinations mostly show very low performance below $1 \%$ because of the poor charge transport property [23]. Therefore, heterovalent substitution of silver ions $\left(\mathrm{Ag}^{+}\right)$for $\mathrm{A}$ was adopted to design Bi-based light absorbers with high-efficiency.

Such introduced $\mathrm{Ag}^{+}$can connect the neighboring iodobismuthate units, which show more intriguing properties theoretically [24]. Taking $\mathrm{Cs}_{2} \mathrm{AgBiX}_{6}\left(\mathrm{X}=\mathrm{Br}^{-}, \mathrm{Cl}^{-}\right)$ with double perovskites structure as an example, the

\section{Electronic supplementary material The online version of this article (https://doi.org/10.1007/s42452-019-0633-y) contains} supplementary material, which is available to authorized users.

\footnotetext{
$\triangle$ Wenhua Li, $11112013119 @$ bnu.edu.cn; Zhishan Bo, zsbo@bnu.edu.cn | Beijing Key Laboratory of Energy Conversion and Storage Materials, College of Chemistry, Beijing Normal University, Beijing 100875, China. ${ }^{2}$ School of Materials Science and Engineering, Lanzhou University of Technology, Lanzhou 730050, China.
}

SN Applied Sciences (2019) 1:620 | https://doi.org/10.1007/s42452-019-0633-y 
combination of monovalent and trivalent cation has been reported in it [25]. The band gap turns out to be indirect for most of these materials, and the indirect band gap would restrict them used as absorbers in single junction photovoltaic cells $[26,27]$. Moreover, $\mathrm{Ag}^{+}$can replace $\mathrm{Cs}^{+}$ completely and form a series of different $\mathrm{Ag}_{x} \mathrm{Bi}_{y} \mathrm{I}_{z}(0<\mathrm{x}<4$, $0<y<3,5<z<7)$ compounds. For devices based on these compounds like $\mathrm{AgBi}_{2} \mathrm{I}_{7}, \mathrm{Ag}_{2} \mathrm{Bil}_{5}$ and $\mathrm{Ag}_{3} \mathrm{Bil}_{6}$, the best PCEs of $1.22 \%, 2.1 \%$ and $4.3 \%$ have been demonstrated, respectively [28-30], that comparable to other $\mathrm{Pb}$-free PSCs. Meanwhile, their stability is obviously superior to the typical methylamine lead halides exposed in humid air. This signifies that silver-bismuth halide materials can be promising as potential candidates for fabrication of airstable, lead-free PSCs. Noticeably, people mainly focus on the silver iodobismuthates materials as their relatively low $E_{\mathrm{g}}$ and high solubility at room temperature. In comparison, the bromide-based materials mostly have been limited to theoretical investigations. Both the structural and physical properties in experiment are yet reported neither the photovoltaic performance. The main constraint is due to the absence of solvent suitable to prepare precursor solution.

Herein, we report the utilization of $n$-butylamine to get a yellowish, homogeneous precursor solution. Furthermore, the $\mathrm{Ag}_{3} \mathrm{BiBr}_{6}$ perovskite material as film was made and its physical properties were demonstrated for the first time. Typically, the precursor solution with a mixture of silver bromide $(\mathrm{AgBr})$ and bismuth bromide $\left(\mathrm{BiBr}_{3}\right)$ at molar ratio of $\mathrm{AgBr}: \mathrm{BiBr}=3: 1$ was spin-coated under ambient atmosphere subsequently with thermal annealing treatment. X-ray diffraction (XRD), computer calculations and energy-dispersive $\mathrm{X}$-ray (EDX) spectrometry were used to identify the formation of $\mathrm{Ag}_{3} \mathrm{BiBr}_{6}$. We found that the obtained $\mathrm{Ag}_{3} \mathrm{BiBr}_{6}$ material has better thermal stability with decomposition temperatures up to $240{ }^{\circ} \mathrm{C}$ and also show inspiring stability over 30 days under ambient conditions by completely replacing I halogen. Specifically, we develop $\mathrm{Ag}_{3} \mathrm{BiBr}_{6}$ as light absorber to harvest solar energy by fabricating solar cells with the cell configuration (glass/ fluorine-doped tin oxide (FTO) electrode/compact $\mathrm{TiO}_{2} /$ $\mathrm{Ag}_{3} \mathrm{BiBr}_{6} /$ poly(3-hexylthiophene) (P3HT)/gold electrode). The best PCE of $0.033 \%$ for $\mathrm{Ag}_{3} \mathrm{BiBr}_{6}$ solar cells was preliminarily exhibited.

\section{Experimental}

Titanium tetra-iso-propanoate (TTIP, 97\%, Sigma-Aldrich), 1-butanol (99.9\%, Sigma-Aldrich), hydrochloric acid (36-38 wt\% in water), silver bromide(AgBr, 99.998\%, Alfa Aesar), bismuth(III) bromide ( $\mathrm{BiBr}_{3}, 99 \%$, Alfa Aesar), n-butylamine (99.0\%, Alfa Aesar) and poly(3-hexylthiophene)
(P3HT, One Material) were used as received without any purification.

Initially FTO coated glass substrates $(15 \times 20 \mathrm{~mm}, 15 \Omega /$ $\mathrm{cm}^{2}$ resistances) were etched with zinc powder and $\mathrm{HCl}$ (2 M). Then these FTO glass substrates were cleaned sequentially by ultrasonication in detergent, deionized water, acetone, and isopropanol for $20 \mathrm{~min}$, respectively. Afterwards, FTO glasses were treated with an alkaline solution (with the volume ratio of $\mathrm{H}_{2} \mathrm{O}: \mathrm{H}_{2} \mathrm{O}_{2}: \mathrm{NH}_{3}(\mathrm{aq})=5: 1: 1$ ) at $160^{\circ} \mathrm{C}$ for $30 \mathrm{~min}$, and then washed with deionized water several times to remove the residual alkaline solution. The compact $\mathrm{TiO}_{2}$ layer was deposited by spin-coating $1.0 \mathrm{M}$ titanium tetra(isopropanoate) 1-butanol solution (containing $1.0 \mathrm{M} \mathrm{HCl}$ ) onto the FTO substrates at $3000 \mathrm{rpm}$ for $60 \mathrm{~s}$. Then the substrates were dried at $125^{\circ} \mathrm{C}$ for $15 \mathrm{~min}$ to remove the solvent and sintered at $500^{\circ} \mathrm{C}$ for $60 \mathrm{~min}$ [31]. After cooling down to room temperature, the perovskite layers were deposited by spin-coating the precursor solution $(0.5087 \mathrm{mmol}$ bismuth bromide and $0.2544 \mathrm{mmol}$ silver bromide that dissolved in $\mathrm{n}$-butylamine, $500 \mu \mathrm{L}$ ) at $3000 \mathrm{rpm}$ for $60 \mathrm{~s}$ at room temperature. The precursor solution was stirred for $30 \mathrm{~min}$ to form clear, yellow solution before they were used. Then the substrates were heated at $150{ }^{\circ} \mathrm{C}$ for $30 \mathrm{~min}$ in air. The resulting film was then quenched to room temperature that was yellowish. For deposition of the hole transport layers, $\mathrm{P} 3 \mathrm{HT}$ solution (15 mg/mL in 1,2-dichlorobenzene) was spin-coated at $2000 \mathrm{rpm}$ for $30 \mathrm{~s}$ in ambient atmosphere and then coated substrates were further annealed at $100^{\circ} \mathrm{C}$ for $15 \mathrm{~min}$ to remove the remaining solvent [20]. Finally, $80 \mathrm{~nm}$ of $\mathrm{Ag}$ was deposited by thermal evaporation on the top of the hole transport layer as the back contact under $10^{-6} \mathrm{mbar}$.

To determine the crystal structure of $\mathrm{Ag}_{3} \mathrm{BiBr}_{6}$, the unit cell parameters of $\mathrm{Ag}_{3} \mathrm{Bil}_{6}$ were adopted and $\mathrm{I}^{-}$was replaced by $\mathrm{Br}^{-}$. In details, the lattice constant in $\mathrm{Ag}_{3} \mathrm{BiBr}_{6}$ could be calculated by using the formula: $k=\left(r_{\mathrm{Br}}^{-}+3 / 4 r_{\mathrm{Ag}}^{+}+1 / 4 r_{\mathrm{Bi}}^{3+}\right) /\left(r_{1}^{-}+3 / 4 r_{\mathrm{Ag}}^{+}+1 / 4 r_{\mathrm{Bi}}^{3+}\right)\left(r_{\mathrm{Br}}^{-}=195 \mathrm{pm}\right.$, $r_{1}^{-}=216 \mathrm{pm}, r_{\mathrm{Bi}}^{3+}=108 \mathrm{pm}$ and $\left.r_{\mathrm{Ag}}^{+}=126 \mathrm{pm}\right)$. The theoretical XRD pattern of $\mathrm{Ag}_{3} \mathrm{BiBr}_{6}$ was calculated by Mercury 3.7 software (The Cambridge Crystallographic Data Centre, CCDC) based on the lattice constant. The calculated XRD pattern matches well with the experimental XRD pattern as we will discuss below, thus confirming the crystal structure of $\mathrm{Ag}_{3} \mathrm{BiBr}_{6}$.

The crystallographic properties of the perovskite thin films deposited on glass substrate were investigated by a Bruker X-ray diffractometer (XRD) with $\mathrm{Cu} \mathrm{Ka}$ as the radiation source. The stability of $\mathrm{Ag}_{3} \mathrm{BiBr}_{6}$ films were tested in the ambient air, with a relative humidity of $50 \%$. The UV-vis (ultraviolet-visible) absorption spectra were recorded by a PerkinElmer UV-vis spectrometer model Lambda 750. The glass substrate was measured as reference. PL (photoluminescence) spectra and time resolved 
PL spectra of the fabricated thin films were obtained on PL spectrometer FLS 900 (Edinburgh Instruments). The emission for time resolved measurements was set at $463 \mathrm{~nm}$. UPS (ultraviolet photoelectron spectroscopy) was recorded using a Kratos AXIS UTRADLD UPS/XPS system (Kratos analytical, Manchester, UK). The UPS measurement was carried out on an integrated ultra-high vacuum system $\left(3.0 \times 10^{-8}\right.$ Torr) using the $\mathrm{He}(\mathrm{I})(21.22 \mathrm{eV})$ line in order to shift the spectra from the spectrometer threshold. The $\mathrm{Ag}_{3} \mathrm{BiBr}_{6}$ thin films for UPS measurement were prepared on silicon substrate. SEM (scanning electron microscope) images and EDX (energy dispersive X-Ray spectroscopy) data were obtained by S-4800 (Hitachi) field-emission scanning electron microscope (FESEM). The samples used for SEM and EDX measurements were fabricated on $\mathrm{TiO}_{2} /$ $\mathrm{FTO} /$ glass. Thermal gravimetric analysis (TGA) and differential scanning calorimetry (DSC) measurements were performed on TA2100 and Perkin-Elmer Diamond DSC instrument, respectively, under a nitrogen atmosphere at a heating rate of $10{ }^{\circ} \mathrm{C} / \mathrm{min}$. Powder samples of $\mathrm{Ag}_{3} \mathrm{BiBr}_{6}$ for TGA and DSC measurements were obtained by heating the stoichiometric ratio of precursors in $n$-butylamine in a Petri dish at $150^{\circ} \mathrm{C}$ for about $4 \mathrm{~h}$ to remove completely the solvent.

The photovoltaic performance of the devices was measured using the Agilent B2902A Source Meter under the illumination of AM $1.5 \mathrm{G}\left(100 \mathrm{~mW} \mathrm{~cm}^{-2}\right)$ AAA class solar simulator (model XES-301S, SAN-EI) in nitrogen and the solar cells were masked with a black aperture to define the active area of $0.04 \mathrm{~cm}^{2}$. The white light intensity was calibrated with a standard single-crystal Si solar cell.

\section{Results and discussion}

Compared with $\mathrm{BiBr}_{3}$, the $\mathrm{AgBr}$ precursor is hardly soluble in polar aprotic solvents such as dimethylformamide (DMF) and dimethyl sulfoxide (DMSO), which tend to solubilize the metal halides. It is well-known that primary alkylamine groups $\left(\mathrm{R}-\mathrm{NH}_{2}\right)$ are capable of solubilizing $\mathrm{AgX}\left(\mathrm{X}=\mathrm{I}^{-}\right.$, $\mathrm{Br}^{-}$and $\mathrm{Cl}^{-}$) [29], so we employed n-butylamine to prepare the precursor solution. $\mathrm{Ag}_{3} \mathrm{BiBr}_{6}$ films were deposited by spin-coating $n$-butylamine based precursor solution of $\mathrm{AgBr}$ and $\mathrm{BiBr}_{3}$ (with the molar ratio of 3:1) on top of glass/ $\mathrm{FTO} / \mathrm{TiO}_{2}$ substrate at room temperature of about $16^{\circ} \mathrm{C}$ and subsequently annealing in an ambient atmosphere at $150^{\circ} \mathrm{C}$ for $30 \mathrm{~min}$. We found that the some small cracks were likely to appear on the surface of $\mathrm{Ag}_{3} \mathrm{BiBr}_{6}$ films while spin-coating at room temperature over $25^{\circ} \mathrm{C}$. This is probably due to the low boiling point of $n$-butylamine, and it easily evaporated from the film surface when films did not completely form yet. A scheme of the complete synthesis procedure is given in Scheme 1. The prepared film was

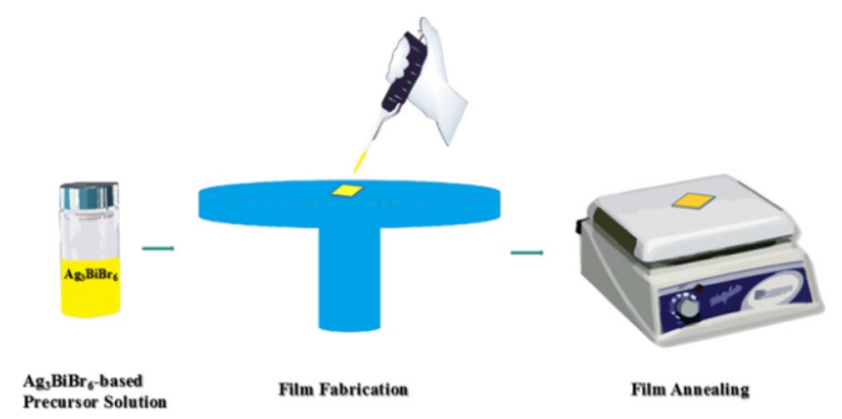

Scheme 1 Process for fabricating the $\mathrm{Ag}_{3} \mathrm{BiBr}_{6}$ films

firstly measured with single crystal X-ray diffractometer. In Fig. 1, there is no reference patterns present because it is not available in database. Fortunately, it is reasonable to propose that the patterns of $\mathrm{Ag}_{3} \mathrm{Bil}_{6}$ are similar to that of $\mathrm{Ag}_{3} \mathrm{Bil}_{6}$ [32]. Taking into account both the lattice parameters of $\mathrm{Ag}_{3} \mathrm{Bil}_{6}$ and the smaller radius of $\mathrm{Br}^{-}(195 \mathrm{pm})$ than $\mathrm{I}^{-}(216 \mathrm{pm})$, the corresponding lattice parameters of hexagonal $\mathrm{Ag}_{3} \mathrm{BiBr}_{6}$ were estimated as $a=b=409.25(6)$ $\mathrm{pm}, \mathrm{c}=1956.14(4) \mathrm{pm}$. The main crystallographic data of $\mathrm{Ag}_{3} \mathrm{BiBr}_{6}$ were demonstrated in Table 1. Bismuth and silver share octahedral sites with different mass ratio in the structure as showed in the Fig. 1 a.

Based on this proposed lattice structure, we further simulated the XRD pattern for $\mathrm{Ag}_{3} \mathrm{BiBr}_{6}$ by using the Mercury 3.7 software. In Fig. 1b, both the experimental and calculated XRD patterns are exhibited. It is clear that these two patterns are consistent well with each other. In addition, the presence of $\mathrm{BiBr}_{3}$ and/or $\mathrm{AgBr}$ can be excluded by comparing their diffraction peaks to $\mathrm{Ag}_{3} \mathrm{BiBr}_{6}$ (Figure S1), which confirms the successful formation of $\mathrm{Ag}_{3} \mathrm{BiBr}_{6}$. The formation of $\mathrm{Ag}_{3} \mathrm{BiBr}_{6}$ material can also be verified by EDX spectrometry (Figure S2). These results indicate that the obtained product is not simply a mixture of $\mathrm{BiBr}_{3}$ and $\mathrm{AgBr}$. The $\mathrm{Ag}_{3} \mathrm{BiBr}_{6}$ films are highly moisture- and air-stable for over 30 days, as is evident by the XRD pattern (Figure S3).

Thermo gravimetric analysis (TGA) and differential scanning calorimeter (DSC) were employed to test thermal stability of $\mathrm{Ag}_{3} \mathrm{BiBr}_{6}$. It is thermally stable up to $240^{\circ} \mathrm{C}$ as inferred from the TGA and DSC data given in Fig. 2. TGA shows two step decomposition with the first step starting at around $240^{\circ} \mathrm{C}$ associated with around $44 \%$ weight loss (loss of $\mathrm{AgBr}$ ). The stability temperature of $240^{\circ} \mathrm{C}$ is high enough for processing the material. There is no phase change observed in the range of $60-160^{\circ} \mathrm{C}$ as DSC curve shown, which is a high enough range to operate solar cells, and these similar results were also observed in another study [32].

The optical bandgap of $\mathrm{Ag}_{3} \mathrm{BiBr}_{6}$ was calculated to be $2.58 \mathrm{eV}$ according to the equation: $E_{\text {gopt }}=1240 / \lambda_{\text {onset }}$. The photoluminescence (PL) spectrum of $\mathrm{Ag}_{3} \mathrm{BiBr}_{6}$ is also shown in the inset, displaying a maximum emission at 
Fig. 1 a Crystal structure of $\mathrm{Ag}_{3} \mathrm{BiBr}_{6}$ (space group R-3 m). b Calculated and experimental XRD patterns of $\mathrm{Ag}_{3} \mathrm{BiBr}_{6}$ film

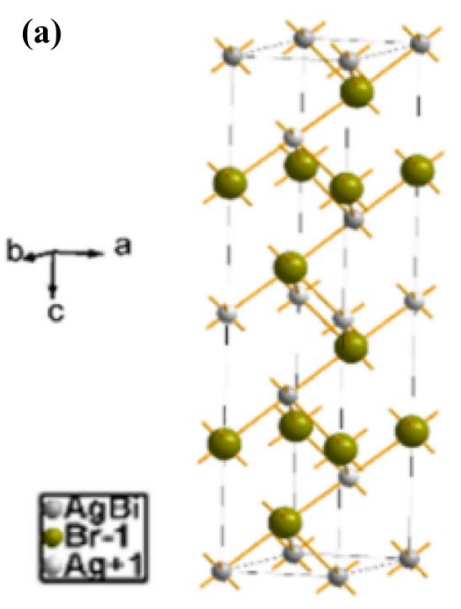

Table 1 Crystallographic data for $\mathrm{Ag}_{3} \mathrm{BiBr}_{6}$

\begin{tabular}{ll}
\hline Empirical formula & $\mathrm{Ag}_{3} \mathrm{BiBr}_{6}$ \\
Formula weight & 1012.10 \\
Crystal system & Hexagona \\
Space group & $\mathrm{R}-3 \mathrm{~m}(166)$ \\
$\mathrm{a}=\mathrm{b}, \mathrm{c}(\AA)$ & $4.0925(6), 19.5614(4)$ \\
$\mathrm{a}, \beta, \gamma\left({ }^{\circ}\right)$ & $90,90,120$ \\
Volume $\left(\AA^{3}\right)$ & 283.7 \\
$\mathrm{Z}, \rho_{\text {calcd }}\left(\mathrm{g} \mathrm{cm}^{-3}\right)$ & 1 \\
\hline
\end{tabular}

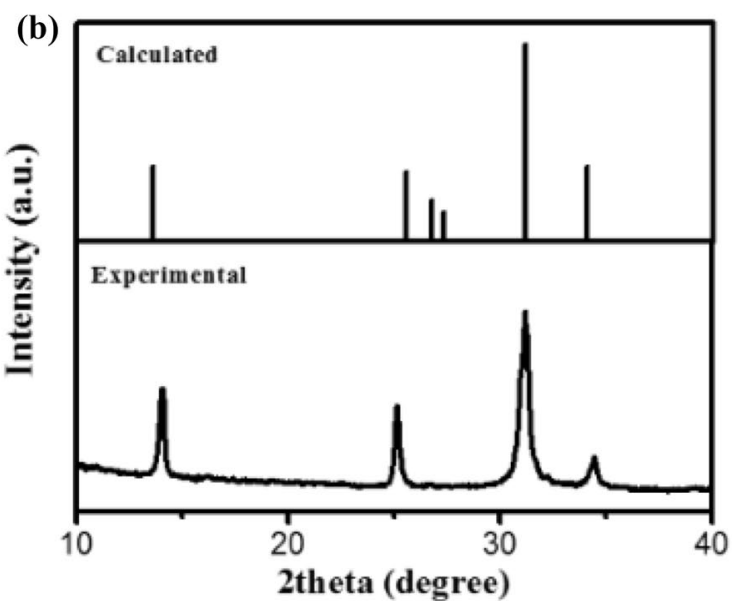

Fig. 2 a TGA and $\mathbf{b}$ DSC curves of $\mathrm{Ag}_{3} \mathrm{BiBr}_{6}$ under $\mathrm{N}_{2}$ atmosphere
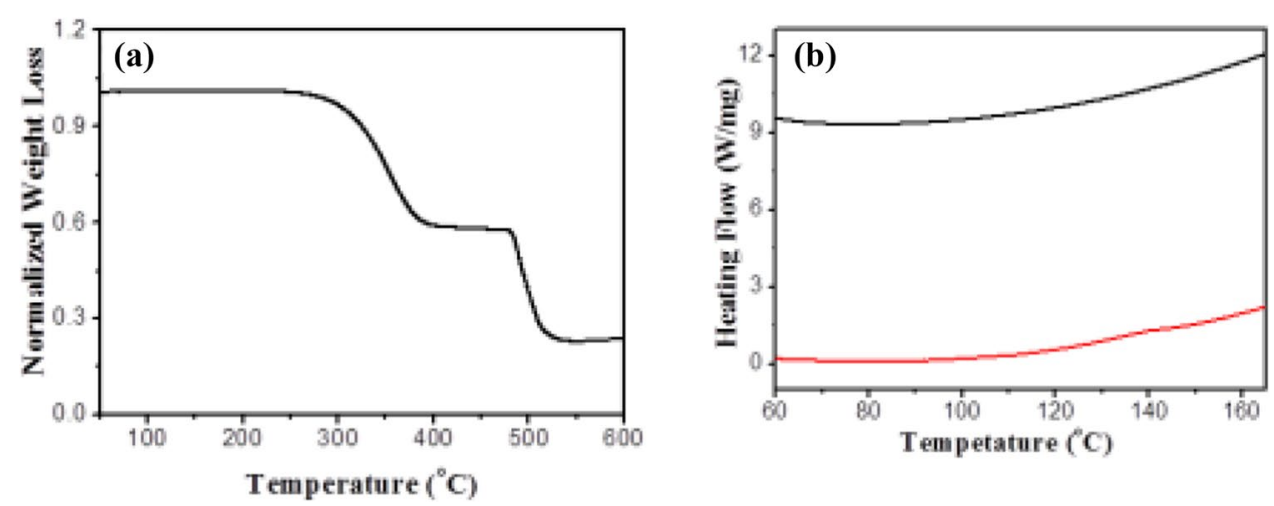

$463 \mathrm{~nm}$, with the Stokes shift of $63 \mathrm{~nm}$. Fitting the curves with an exponential diffusion model results in the decay time of $0.81 \mathrm{~ns}$ for $\mathrm{Ag}_{3} \mathrm{BiBr}_{6}$ (Figure S4). Ultraviolet photoelectron spectroscopy (UPS) was used to study the electrochemical property of $\mathrm{Ag}_{3} \mathrm{BiBr}_{6}$. In Fig. 3b, the cutoff ( $E_{\text {cutoff }}$ ) energy region of $16.45 \mathrm{eV}$ and onset $\left(E_{\text {onset }}\right)$ energy region of $1.41 \mathrm{eV}$ are observed for $\mathrm{Ag}_{3} \mathrm{BiBr}_{6}$. Using the equations of $E_{\mathrm{HOMO}}=21.22-\left(E_{\text {cutoff }}-E_{\text {onset }}\right)$ and $E_{\mathrm{LUMO}}=E_{\mathrm{HOMO}}+E_{\mathrm{g}}$, the HOMO energy level of $-6.2 \mathrm{eV}$ and LUMO of $-3.6 \mathrm{eV}$ can be deduced, respectively.
Fig. 3 a UV-vis absorption spectrum and the PL spectrum of $\mathrm{Ag}_{3} \mathrm{BiBr}_{6}$. b UPS spectrum in high binding-energy region of $\mathrm{Ag}_{3} \mathrm{BiBr}_{6}$ to determine the $E_{\text {cutoff }}$ level $(16.45 \mathrm{eV})$. The inset presents detail of the $E_{\text {onset }}$ level $(1.41 \mathrm{eV})$
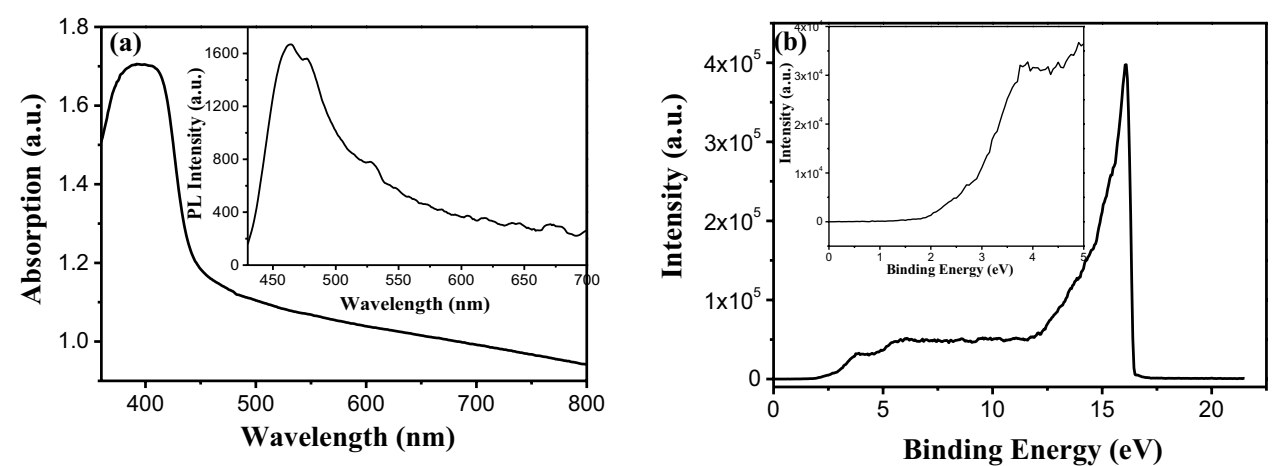
In view of the intrinsic properties investigated above, we fabricated $\mathrm{Ag}_{3} \mathrm{BiBr}_{6}$ based solar cells with the configuration (FTO) electrode/compact $\mathrm{TiO}_{2} / \mathrm{Ag}_{3} \mathrm{BiBr}_{6} / \mathrm{P} 3 \mathrm{HT} /$ Ag electrode. Compact $\mathrm{TiO}_{2}$ and $\mathrm{P} 3 \mathrm{HT}$ are employed as electron transporting and hole transporting materials (ETM and HTM), respectively for our devices. The crystallized $\mathrm{Ag}_{3} \mathrm{BiBr}_{6}$ film annealed at $150{ }^{\circ} \mathrm{C}$ acts as the active layer and its surface morphology was characterized using scanning electron microscope (SEM) as shown in Fig. 4a. It reveals a basically continuous and fully-covered Film. Meanwhile, there are a spot of agglomerates observed in the films. This could be induced by the fast evaporation of n-butylamine with relative low boiling point during the spin-coating procedure. In Fig. 4b, each function layer of the prepared device could be clearly distinguished from the cross-sectional SEM image. An energy band diagram can be made referring to the relative energy levels discussed above. Wherein, the energy levels of $\mathrm{TiO}_{2}, \mathrm{P} 3 \mathrm{HT}$, and $\mathrm{Ag}$ were obtained from literatures [20,33, 34]. This implies that the charge transfer can successfully occur at the different interfaces for these devices (Fig. 4c).

To estimate the photovoltaic performance of these $\mathrm{Ag}_{3} \mathrm{BiBr}_{6}$-based devices, we measured the current density-voltage $(J-V)$ characteristics of that fabricated under the optimal conditions. The $J-V$ curves in Fig. $4 d$ were obtained with a 20 ms scanning delay under standard air-mass 1.5 global (AM $1.5 \mathrm{G}$ ) illumination. It gives a short circuit current density $\left(J_{\mathrm{SC}}\right)$ of $0.12 \mathrm{~mA} / \mathrm{cm}^{2}$, open circuit voltage $\left(V_{O C}\right)$ of $0.61 \mathrm{~V}$ and fill factor $(F F)$ of $44.83 \%$, resulting in a final PCE of $0.033 \%$. In order to clarify the photovoltaic effect of $\mathrm{Ag}_{3} \mathrm{BiBr}_{6}$ material in these devices, we fabricated control devices without $\mathrm{Ag}_{3} \mathrm{BiBr}_{6}$ as well. As the $J-V$ curve shown in Figure $\mathrm{S} 5$, the PCE is as low as less than $0.0005 \%$. Therefore, $\mathrm{Ag}_{3} \mathrm{BiBr}_{6}$ could be a promising photoelectric material. Notably, there is almost no hysteresis behavior manifested in these $\mathrm{Ag}_{3} \mathrm{BiBr}_{6}$-based devices, indicating the $\mathrm{Ag}_{3} \mathrm{BiBr}_{6}$ films are of high quality without the large density of defects inside. Additionally, we tested many more devices and the corresponding performance parameters summarized in Table S1 testify the encouraging reproducibility of efficiency for devices. Besides, stability is also an important factor to evaluate the photovoltaic performance of solar cells. Accordingly, we investigated the stability of these $\mathrm{Ag}_{3} \mathrm{BiBr}_{6}$-based devices, and the PCE still maintains more than $95 \%$ of their initial efficiency after 7 days of exposure to ambient conditions without any encapsulation (Figure S6). Overall, even the PCE of $\mathrm{Ag}_{3} \mathrm{BiBr}_{6}$-based device is much lower than that of
Fig. 4 a Cross-sectional SEM image of the solar cell with the configuration of $\mathrm{FTO} / \mathrm{c}-\mathrm{TiO}_{2} /$ $\mathrm{Ag}_{3} \mathrm{BiBr}_{6} / \mathrm{P} 3 \mathrm{HT} / \mathrm{Ag}$. b Surface image of $\mathrm{Ag}_{3} \mathrm{BiBr}_{6}$ deposited on deposited on $\mathrm{FTO} / \mathrm{c}-\mathrm{TiO}_{2}$. c Relative energy band diagram for $\mathrm{Ag}_{3} \mathrm{BiBr}_{6}$. $\mathbf{d} J-V$ curves in forward- and reverse-scan modes for $\mathrm{Ag}_{3} \mathrm{BiBr}_{6}$-based devices
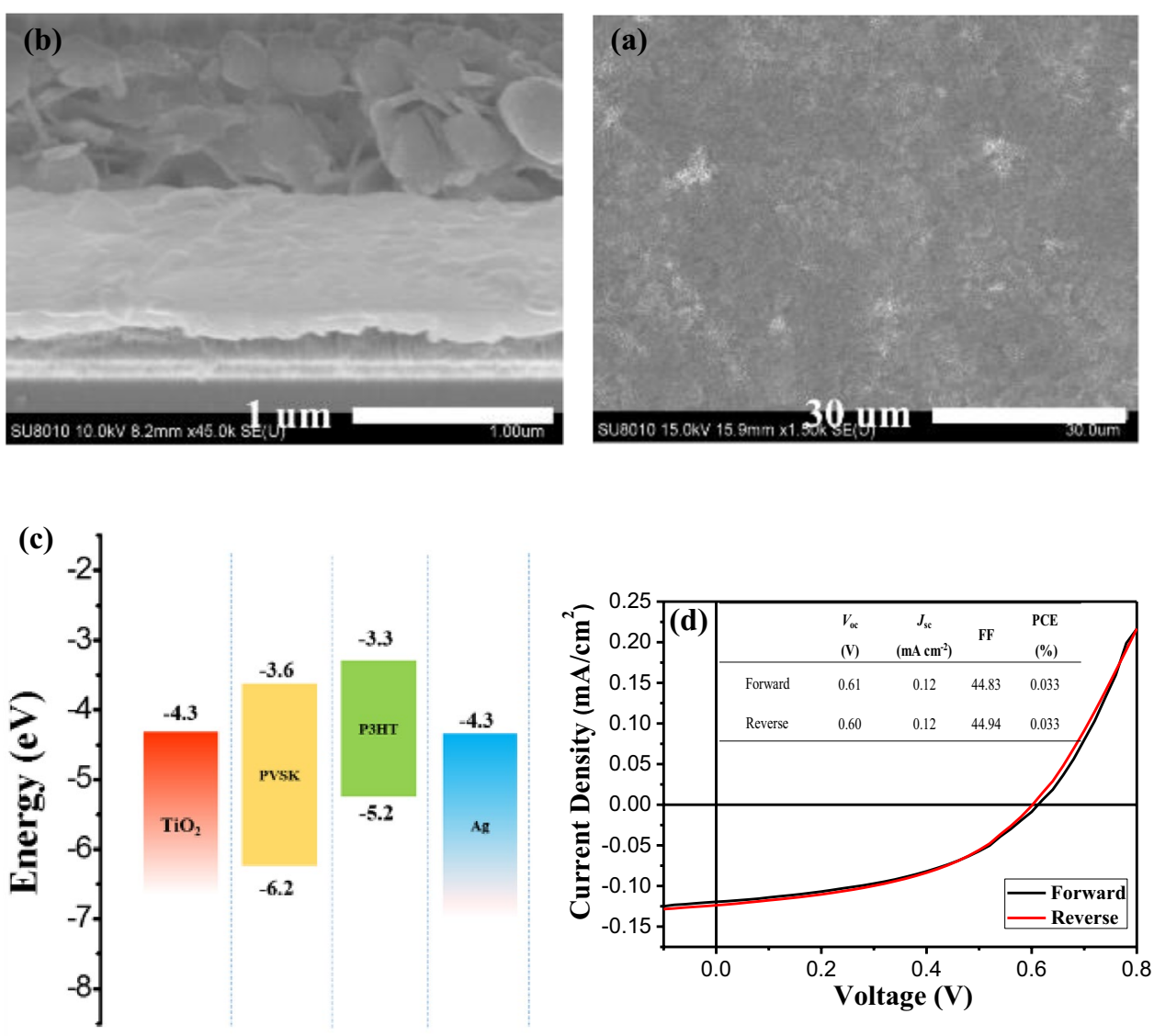

SN Applied Sciences A SPRINGer NATURE journal 
the other PSCs for the moment, the successful preparation of $\mathrm{Ag}_{3} \mathrm{BiBr}_{6}$ still extends the research field of photoelectric lead-free and stable materials.

\section{Conclusion}

In summary, the $\mathrm{Ag}_{3} \mathrm{BiBr}_{6}$ material and $\mathrm{Ag}_{3} \mathrm{BiBr}_{6}$-based PSCs were for the first time fabricated. We have demonstrated that solution-processed $\mathrm{Ag}_{3} \mathrm{BiBr}_{6}$ films were readily prepared using a flexible spin-coating method followed by a mild thermal annealing. $\mathrm{Ag}_{3} \mathrm{BiBr}_{6}$ is crystallized in the hexagonal perovskite phase, and the resulting $\mathrm{Ag}_{3} \mathrm{BiBr}_{6}$ is comparable to calculated XRD pattern. $\mathrm{Ag}_{3} \mathrm{BiBr}_{6}$-based PSCs yield a preliminary efficiency of $0.033 \%$ with relatively high $\mathrm{V}_{\mathrm{OC}}$ of $0.61 \mathrm{~V}$. The $\mathrm{Ag}_{3} \mathrm{BiBr}_{6}$-based solar cells is leadfree and air-stable. To optimize the $\mathrm{Ag}_{3} \mathrm{BiBr}_{6}$ films morphology may be an effective strategy for further improving the device performance. This is the first demonstration of $\mathrm{Ag}_{3} \mathrm{BiBr}_{6}$ light-absorbers for solar cell applications, which may inspire more research work to develop and use the material beyond for solar energy applications.

Acknowledgements This research was supported by NSFC (U1704137, 21574013 and 21404031), Program for Changjiang Scholars and Innovative Research Team in University.

\section{Compliance with ethical standards}

Conflict of interest The authors declare that they have no conflict of interest.

\section{References}

1. Kojima A, Teshima K, Shirai Y, Miyasaka T (2009) Organometal halide perovskites as visible-light sensitizers for photovoltaic cells. J Am Chem Soc 131:6050-6051

2. Lee MM, Teuscher J, Miyasaka T, Murakami TN, Snaith HJ (2012) Efficient hybrid solar cells based on meso-superstructured organometal halide perovskites. Science 338:643-647

3. Burschka J, Pellet N, Moon S-J, Humphry-Baker R, Gao P, Nazeeruddin MK, Grätzel M (2013) Sequential deposition as a route to high-performance perovskite-sensitized solar cells. Nature 499:316

4. Liu M, Johnston MB, Snaith HJ (2013) Efficient planar heterojunction perovskite solar cells by vapour deposition. Nature 501:395

5. Jeon NJ, Noh JH, Kim YC, Yang WS, Ryu S, Seok SI (2014) Solvent engineering for high-performance inorganic-organic hybrid perovskite solar cells. Nat Mater 13:897

6. Saliba M, Matsui T, Seo J-Y, Domanski K, Correa-Baena J-P, Nazeeruddin MK, Zakeeruddin SM, Tress W, Abate A, Hagfeldt A, Grätzel M (2016) Cesium-containing triple cation perovskite solar cells: improved stability, reproducibility and high efficiency. Energy Environ Sci 9:1989-1997
7. NREL's "best research-cell efficiencies" chart. https://www.nrel. gov/pv/assets/pdfs/pv-efficiencies-07-17-2018.pdf. Accessed 18 July 2018

8. Babayigit A, Ethirajan A, Muller M, Conings B (2016) Toxicity of organometal halide perovskite solar cells. Nat Mater 15:47

9. Boix PP, Agarwala S, Koh TM, Mathews N, Mhaisalkar SG (2015) Perovskite solar cells: beyond methylammonium lead iodide. J Phys Chem Lett 6:898-907

10. Endres J, Kulbak M, Zhao L, Rand BP, Cahen D, Hodes G, Kahn $\mathrm{A}$ (2017) Electronic structure of the $\mathrm{CsPbBr} 3$ /polytriarylamine (PTAA) system. J Appl Phys 121:035304

11. Grätzel M (2014) The light and shade of perovskite solar cells. Nat Mater 13:838

12. Hao F, Stoumpos CC, Cao DH, Chang RPH, Kanatzidis MG (2014) Lead-free solid-state organic-inorganic halide perovskite solar cells. Nat Photonics 8:489

13. Kumar MH, Dharani S, Leong WL, Boix PP, Prabhakar RR, Baikie T, Shi C, Ding H, Ramesh R, Asta M, Graetzel M, Mhaisalkar SG, Mathews N (2014) Lead-free halide perovskite solar cells with high photocurrents realized through vacancy modulation. Adv Mater 26:7122-7127

14. Lee SJ, Shin SS, Kim YC, Kim D, Ahn TK, Noh JH, Seo J, Seok SI (2016) Fabrication of efficient formamidinium tin iodide perovskite solar cells through SnF2-pyrazine complex. J Am Chem Soc 138:3974-3977

15. Noel NK, Stranks SD, Abate A, Wehrenfennig C, Guarnera S, Haghighirad A-A, Sadhanala A, Eperon GE, Pathak SK, Johnston MB, Petrozza A, Herz LM, Snaith HJ (2014) Lead-free organic-inorganic tin halide perovskites for photovoltaic applications. Energy Environ Sci 7:3061-3068

16. Hu H, Dong B, Zhang W (2017) Low-toxic metal halide perovskites: opportunities and future challenge. J Mater Chem A 5:11436-11449

17. Hoefler SF, Trimmel G, Rath T (2017) Progress on lead-free metal halide perovskites for photovoltaic applications: a review. Monatshefte für Chemie Chem Mon 148:795-826

18. Lyu M, Yun J-H, Chen P, Hao M, Wang L (2017) Addressing toxicity of lead: progress and applications of low-toxic metal halide perovskites and their derivatives. Adv Energy Mater 7:1602512

19. Johansson MB, Zhu H, Johansson EM (2016) Extended photoconversion spectrum in low-toxic bismuth halide perovskite solar cells. J Phys Chem Lett 7:3467-3471

20. Lyu $M$, Yun J-H, Cai M, Jiao Y, Bernhardt PV, Zhang M, Wang $Q$, Du A, Wang H, Liu G, Wang L (2016) Organic-inorganic bismuth (III)-based material: a lead-free, air-stable and solutionprocessable light-absorber beyond organolead perovskites. Nano Res 9:692-702

21. Park BW, Philippe B, Zhang X, Rensmo H, Boschloo G, Johansson EM (2015) Bismuth based hybrid perovskites A3Bi2 I9 (A: methylammonium or cesium) for solar cell application. Adv Mater 27:6806

22. Saparov B, Hong F, Sun J-P, Duan H-S, Meng W, Cameron S, Hill IG, Yan Y, Mitzi DB (2015) Thin-film preparation and characterization of Cs3Sb219: a lead-free layered perovskite semiconductor. Chem Mater 27:5622-5632

23. Liang L, Gao P (2018) Lead-free hybrid perovskite absorbers for viable application: Can we eat the cake and have it too? Adv Sci 5:1700331

24. Chai W-X, Wu L-M, Li J-Q, Chen L (2007) Silver lodobismuthates: syntheses, structures, properties, and theoretical studies of [Bi2Ag2I102-]n and [Bi4Ag2I162-]n. Inorg Chem 46:1042-1044

25. Greul E, Petrus ML, Binek A, Docampo P, Bein T (2017) Highly stable, phase pure $\mathrm{Cs} 2 \mathrm{AgBiBr} 6$ double perovskite thin films for optoelectronic applications. J Mater Chem A 5:19972-19981 
26. Slavney AH, Hu T, Lindenberg AM, Karunadasa HI (2016) A bismuth-halide double perovskite with long carrier recombination lifetime for photovoltaic applications. J Am Chem Soc 138:2138

27. Savory CN, Walsh A, Scanlon DO (2016) Can Pb-free halide double perovskites support high-efficiency solar cells? ACS Energy Lett 1:949-955

28. Jung KW, Sohn MR, Lee HM, Yang IS, Sung SD, Kim J, Wei-Guang Diau E, Lee WI (2018) Silver bismuth iodides in various compositions as potential $\mathrm{Pb}$-free light absorbers for hybrid solar cells. Sustain Energy Fuels 2:294-302

29. Kim Y, Yang Z, Jain A, Voznyy O, Kim GH, Liu M, Quan LN, Garcia de Arquer FP, Comin R, Fan JZ, Sargent EH (2016) Pure cubicphase hybrid iodobismuthates AgBi2 17 for thin-film photovoltaics. Angew Chem 55:9586

30. Turkevych I, Kazaoui S, Ito E, Urano T, Yamada K, Tomiyasu H, Yamagishi H, Kondo M, Aramaki S (2017) Photovoltaic rudorffites: lead-free silver bismuth halides alternative to hybrid lead halide perovskites. ChemSusChem 10:3754-3759

31. Liu J, Wu Y, Qin C, Yang X, Yasuda T, Islam A, Zhang K, Peng W, Chen W, Han L (2014) A dopant-free hole-transporting material for efficient and stable perovskite solar cells. Energy Environ Sci 7:2963-2967

32. Harikesh PC, Mulmudi HK, Ghosh B, Goh TW, Teng YT, Thirumal K, Lockrey M, Weber K, Koh TM, Li S, Mhaisalkar S, Mathews N (2016) $\mathrm{Rb}$ as an alternative cation for templating inorganic leadfree perovskites for solution processed photovoltaics. Chem Mater 28:7496-7504

33. Kou C, Feng S, Li H, Li W, Li D, Meng Q, Bo Z (2017) Molecular "flower" as the high-mobility hole-transport material for perovskite solar cells. ACS Appl Mater Interfaces 9:43855-43860

34. Dong Y, Li W, Zhang X, Xu Q, Liu Q, Li C, Bo Z (2016) Highly efficient planar perovskite solar cells via interfacial modification with fullerene derivatives. Small 12:1098-1104

Publisher's Note Springer Nature remains neutral with regard to jurisdictional claims in published maps and institutional affiliations. 